\title{
EVALUATION OF PHYSICAL AND MECHANICAL PROPERTIES OF WILD CHERRY WOOD HEAT-TREATED USING THE THERMOWOOD PROCESS
}

\author{
Süleyman Korkut ${ }^{1, \wedge}$, Ayhan Aytin ${ }^{2}$
}

\begin{abstract}
The aim of this study is to determine the change of some physical properties (oven-dry density, weight loss, swelling and anti-swelling efficiency) and mechanical properties (compression strength parallel to grain, bending strength, modulus of elasticity in bending, janka-hardness (cross-section, radial, tangential), impact bending strength and tension strength perpendicular to grain) of wild cherry woods after heat treatment under different durations. Specimens are exposed to temperature levels of $212{ }^{\circ} \mathrm{C}$ for time spans of 1,5 and 2,5 h. Based on the findings in this study, the results showed that oven-dry density, swelling, compression strength parallel to grain, bending strength, modulus of elasticity in bending, janka-hardness (Cross-section, Radial, Tangential), impact bending strength and tension strength perpendicular to grain values decreased with increasing treatment time.
\end{abstract}

Keywords: Anti-swelling-efficiency, compression strength, janka-hardness, modulus of elasticity, modulus of rupture, Prunus avium.

\section{INTRODUCTION}

Faced with increasing pressure to reduce the environmental pollution, worldwide wood manufactures started to decrease the amount of chemicals used in wood treatment gradually and are looking for alternative ways to modify wood. The heat treatment of wood at high temperature, as a wood modification method, seems to be an eco-friendly and viable alternative ( $\mathrm{Li}$ et al. 2011).

Heat treatment has been particularly developed in Europe during this last decade leading to commercialization of heat treated timbers of low natural durability wood species such as willow, poplar or birch. The end product, called thermally-modified wood, is produced by mild pyrolysis at temperature range of $160^{\circ} \mathrm{C}$ to $250^{\circ} \mathrm{C}$ under inert atmosphere depending on desired degree of modification. The result is a solid product showing different characteristics compared to its original timber (Brito et al. 2006).

In general, thermal treatment changes the chemical composition of wood, reduces the wood hygroscopicity, equilibrium moisture content (EMC), water absorption (WA), its wettability, extractive contents, availability of the cell wall polymers for fungal decay, and improves the natural quality and properties of the wood such as dimensional stability, water repellency, thermal insulating capacity and resistance to bio-corrosion. Therefore, the thermally-modified wood material has new properties (Mohareb et al. 2012).

A decrease in mechanical properties due to the material loses in cell wall, hemicellulose degradation and the modification of long chain molecules, together with an increased brittleness, is the main drawback of heattreated wood, limiting its use to applications where good mechanical properties are not required (Borrega 2011).

\footnotetext{
${ }^{1}$ Department of Forest Industry Engineering, Faculty of Forestry, Duzce University, 81620,Duzce-Turkey ${ }_{2}^{2}$ Program of Furniture and Decoration, Duzce Vocational School, Duzce University, 81100, Duzce-Turkey. ^Corresponding author : suleymankorkut@hotmail.com Received: 17.09.2013 Accepted: 06.05.2014
} 
Wild cherry (Prunus avium) is a deciduous tree that grows to a height of $15-30 \mathrm{~m}$, with a trunk diameter up to $1,5 \mathrm{~m}$. P. avium is native to Europe, western Turkey, and northwestern Africa. Its wood is hard, reddish brown, and widely used for wood turning, manufacturing cabinet, veneer, and musical instruments (Eşen et al. 2005). Recently, the use of wild cherry wood has grown in popularity in Turkey and surrounding countries due to high demand for this species. Both surface quality and color changes of this species have been investigated previously, but there is limited or no information on how heat treatment would affect its mechanical and physical characteristics. The main objective of this study was to evaluate the effect of thermal treatment on the physical and mechanical properties of wild cherry wood.

\section{EXPERIMENTAL}

\section{Materials}

The sample trees of wild cherry wood (Prunus avium) used for the present study were harvested from a mixed oak-hornbeam wild cherry stand in the Duzce Forest Enterprises, western part of Turkey (ISO 4471, 1982). Sections of 1,5 m were cut from the 2-4 m height of trees to obtain samples for strength property measurements. Boards which are $8 \mathrm{~cm}$ in thickness sawn and sawdust immediately removed from surfaces. Then, boards were stored in an unheated room for air drying (ISO 3129, 1975).

\section{Methods}

Heat treatment was carried out under steam atmosphere with a laboratory kiln from Nova ThermoWood in Gerede, Turkey. Steam is used during the drying and heat treatment as a protective vapor. Protective gas prevents the wood from burning and also affects the chemical changes taking place in wood. The heat treatment was applied according to the method described in the Finnish ThermoWood Handbook (FTWA 2003). At first, the temperature of the kiln was raised near to $100^{\circ} \mathrm{C}$. When the temperature inside the wood had risen to near the same temperature, the kiln temperature was carefully increased up to the actual treatment temperature. The target temperature was $212^{\circ} \mathrm{C}$. The time of heat treatment at the target temperatures were 1,5 and $2,5 \mathrm{~h}$ in every test run. After the heat-treatment phase, the temperature was lowered to 80 to $90{ }^{\circ} \mathrm{C}$ using water spray system. Conditioning was carried out to moisten the heat treated wood and bring its moisture content to $4-7 \%$.

After heat treatment, treated and untreated samples were conditioned at a temperature of $20 \pm 2^{\circ} \mathrm{C}$ with 65 percent relative humidity according to ISO 554. The moisture content of the samples was 6 percent after heat treatment. Following heat treatment in a conditioning room, samples reached to equilibrium moisture content ranging from 8 to 9 percent.

Small and defect-free specimens $(20 \times 20 \times 30 \mathrm{~mm})$ were cut from the boards according to ISO 3131 to determine oven dry densities and swelling (tangential, radial, longitudinal $[\alpha(\mathrm{t}, \mathrm{r}, 1, \mathrm{v})$,$] ; ISO 4859).$

Weight loss after heat treatment was estimated according to the following equation:

$$
\mathrm{WL}(\%)=\left(\mathrm{m}_{0}-\mathrm{m}_{1}\right) / \mathrm{m}_{0} \times 100
$$

where $m_{0}$ is the initial oven dried mass of the wood sample before treatment and $m_{l}$ is the oven dried mass of the same sample after treatment.

The dimensional stability was appraised in terms of the anti-swelling efficiency (ASE). Anti swellingefficiency represents the difference between the swelling of the treated and untreated wood. The anti-swellingefficiency (ASE) was determined after test samples were soaked in water at $21^{\circ} \mathrm{C}$ at a water flow rate of 20 $\mathrm{ml} / \mathrm{s}$ for 7 days. The volumetric swelling coefficients were calculated according to the formula:

$$
\mathrm{S}(\%)=\left(\mathrm{V}_{2}-\mathrm{V}_{1}\right) / \mathrm{V}_{1} \mathrm{x} 100
$$


where $V_{2}$ is the volume of the water saturated wood and $V_{1}$ is the sample volume of the dry untreated or treated wood, respectively.

The percentage of ASE was calculated for the wet and oven dried volumes of the treated and untreated blocks according to:

$$
\operatorname{ASE}(\%)=\left(\mathrm{S}_{\mathrm{c}}-\mathrm{S}_{\mathrm{t}}\right) / \mathrm{S}_{\mathrm{c}} \mathrm{x} 100
$$

where $S_{c}$ is the volumetric swelling coefficient of the control samples (untreated samples) and $S_{t}$ is the volumetric swelling coefficient of the treated samples.

Following the air-drying process, small and clear specimens were cut from the boards according (ISO) to determine compression strength parallel to grain ( $\sigma \mathrm{c} / /$ ) (ISO 3787, 1976), bending strength (MOR) (ISO 3133, 1975), modulus of elasticity in bending (MOE) (ISO 3349, 1975), janka-hardness (Hj) (cross-section, radial, tangential) (ISO 3350, 1975), impact bending strength ( $\sigma \mathrm{i})$ (ISO 3348, 1975) and tension strength perpendicular to grain $\left(\sigma_{t}^{\perp}\right)$ (ISO 3346, 1975). The specimens were then conditioned at $20 \pm 2^{\circ} \mathrm{C}$ with $65 \%$ relative humidity according to ISO 554 (1976). After acclimatization, mechanical properties of the wild cherry wood were determined.

At the end of experiments, moisture contents (M) of specimens were measured according to ISO 3130 (1975) and the moisture content of specimen in which moisture content deviated from $12 \%$ determined. Strength values were corrected (transformed to $12 \%$ moisture content) using the following strength conversion equation:

$$
\delta_{12}=\delta_{\mathrm{m}} *\left[1+\alpha\left(\mathrm{M}_{2}-1_{2}\right)\right]
$$

where $\delta_{12}=$ strength at 12 percent moisture content $(\mathrm{MPa}), \delta_{\mathrm{m}}=$ strength at moisture content deviated from 12 percent (MPa), $\alpha=$ constant value showing relationship between strength and moisture content $(\alpha=0,05$ $0,040,020,0250,0150,04$ and 0,025 for $\sigma_{\mathrm{c} /}, \mathrm{MOR}, \mathrm{MOE}, \sigma_{\mathrm{i}}, \sigma_{\mathrm{t}}$ and $\mathrm{Hj}$, respectively) $\mathrm{M}_{2}=$ moisture content during test $(\%)$.

For the oven-dry density, swelling, compression strength parallel to grain $\left(\sigma_{c^{\prime \prime}}\right)$, bending strength (MOR), modulus of elasticity in bending (MOE), janka-hardness ( $\mathrm{Hj}$ ) (cross-section, radial, tangential), impact bending strength $\left(\sigma_{\mathrm{i}}\right)$ and tension strength perpendicular to grain $\left(\sigma_{\mathrm{t}}^{\perp}\right)$, all multiple comparisons were first subjected to an analysis of variance (ANOVA) and significant differences between mean values of control and treated samples were determined using Duncan's multiple range test.

\section{RESULTS AND DISCUSSION}

Table 1 shows the results of some physical properties (oven-dry density and swelling) and mechanical properties (compression strength parallel to grain, bending strength, modulus of elasticity in bending, jankahardness (cross-section, radial, tangential), impact bending strength and tension strength perpendicular to grain) for $1,5 \mathrm{~h}$ and $2,5 \mathrm{~h}$ of treatment times for all groups. According to the averages, all the parameters decreased with increasing time. Not only the average values changed significantly but also the changes were significant in ANOVA and Duncan's multiple range test results.

It is evident from the results shown in table 1 that the oven-dry density, swelling, compression strength parallel to grain, bending strength, modulus of elasticity in bending, janka-hardness (cross-section, radial, tangential), impact bending strength and tension strength perpendicular to grain values decrease with increasing heat treatment time under the conditions used. The maximum decrease for each parameter was recorded for the treatment carried out at a temperature of $212^{\circ} \mathrm{C}$ and treatment time of $2,5 \mathrm{~h}$. 
The lowest oven-dry density values were around $436 \mathrm{~kg} / \mathrm{m}^{3}$ for wild cherry wood heat-treated at $212^{\circ} \mathrm{C}$ for $2,5 \mathrm{~h}$ while the oven-dry density values of control specimens for wild cherry wood were around $566 \mathrm{~kg} / \mathrm{m}^{3}$.

In relation to the density decrease, Esteves and Pereira (2009) reported that the degradation of hemiceluloses into volatile products and the evaporation of extractives are the main reasons.

Weight loss values generally exhibited a decrease with increasing heat treatment duration compared to the weight loss of control groups of wild cherry wood. The highest weight loss values were obtained from the variations at $212^{\circ} \mathrm{C}$ for $2,5 \mathrm{~h}$ for wild cherry $(\sim 18,70 \%)$. Zaman et al. (2000), with Pinus sylvestris and Betula pendula treated between 200 and $230^{\circ} \mathrm{C}$ during $4 \mathrm{~h}$ and $8 \mathrm{~h}$, and it was determined that the mass losses for pine were smaller than those for birch: for pine, the mass loss varied between $5.7 \%(4 \mathrm{~h})$ and $7,0 \%(8 \mathrm{~h})$ at $205^{\circ} \mathrm{C}$, and between $11,1 \%(4 \mathrm{~h})$ and $15,2 \%(8 \mathrm{~h})$ at $230^{\circ} \mathrm{C}$, and for birch between $6,4 \%(4 \mathrm{~h})$ and $10,2 \%(8 \mathrm{~h})$ at $200^{\circ} \mathrm{C}$ and between $13,5 \%(4 \mathrm{~h})$ and $15,2 \%(8 \mathrm{~h})$ at $220^{\circ} \mathrm{C}$.

Weight loss of wood is one of the most important features in heat treatment and is commonly referred to as an indication of quality. Weight loss depends on wood species, heating medium, temperature, and treatment time (Esteves and Pereira 2009).

The maximum decrease in swelling values was observed when wild cherry samples were treated at $212^{\circ} \mathrm{C}$ for $2,5 \mathrm{~h}$. For wild cherry samples $70,70 \%, 69,78 \%$, and $63,26 \%$ decrease in swelling were observed for longitudinal, radial and tangential directions, respectively. Tjeerdsma et al. (1998) reported that the heat treatment allowed the reduction of swelling (total swelling from dry samples until saturation) from 7,3\% to $5,7 \%$ for Fagus sylvatica and from 4,7\% to 2,8\%, for Pinus sylvestris corresponding to efficiencies of $22 \%$ and $40 \%$, respectively. A decrease in swelling results indicates an increase in dimensional stability, which is required for several uses of wood.

This reduces the swelling of the cell wall preventing or limiting the penetration of (non-) enzymatic systems necessary for fungal decay. Moreover, a reduction in water absorption reduces the overall swelling and shrinkage of wood, hence improving its dimensional stability (Boonstra 2008).

The maximum anti-swelling efficiency for wild cherry $(66,80 \%)$ wood was obtained after heat treatment at $212^{\circ} \mathrm{C}$ for $2,5 \mathrm{~h}$.

Compression strength values of wild cherry wood samples were decreased with increasing treatment time. The maximum reduction in compression strength for wild cherry $(23,59 \%)$ wood was obtained for the treatment at $212^{\circ} \mathrm{C}$ for $2,5 \mathrm{~h}$.

The lowest bending strength for wild cherry was observed when the wood samples were treated at $212^{\circ} \mathrm{C}$ for $2,5 \mathrm{~h}$. The decrease was $50,52 \%$ for wild cherry for $2,5 \mathrm{~h}$ treatment time at $212^{\circ} \mathrm{C}$.

The highest decrease in modulus of elasticity for wild cherry was found to be $39,50 \%$ at $212^{\circ} \mathrm{C}$ for $2,5 \mathrm{~h}$. Shi et al. (2007) studied the mechanical behaviour of Quebec wood species heat-treated using the ThermoWood process and concluded that the modulus of rupture decreased between $0 \%$ and $49 \%$ for heattreated spruce, pine, fir, and aspen, while for birch the modulus increased slightly $(6 \%)$ after the heat treatment. Heat-treated spruce and pine modulus of elasticity decreased between $4 \%$ and $28 \%$; however for fir, aspen, and birch, the modulus generally increased. 


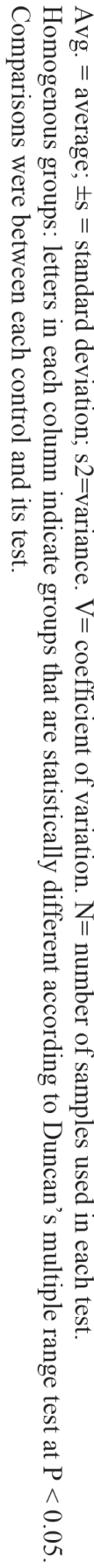

\begin{tabular}{|c|c|c|c|c|}
\hline ñ & 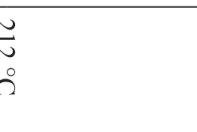 & 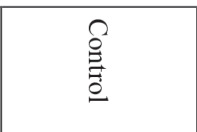 & \multicolumn{2}{|c|}{ 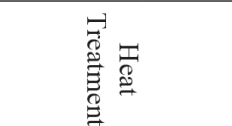 } \\
\hline$\tilde{u}_{n}$ & $\bar{u}_{n}$ & & \multicolumn{2}{|c|}{ 已志 } \\
\hline 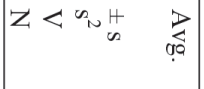 & 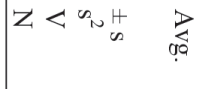 & $Z<\min _{n}$ & \multicolumn{2}{|c|}{$\Xi$} \\
\hline 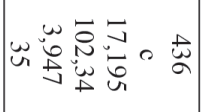 & 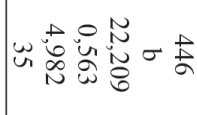 & 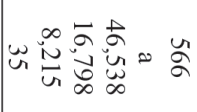 & 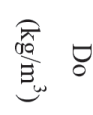 & 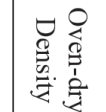 \\
\hline 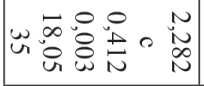 & 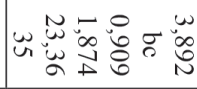 & 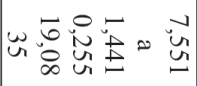 & के & \multirow{4}{*}{ 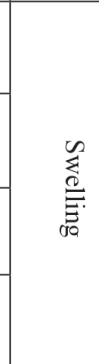 } \\
\hline 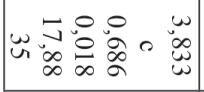 & 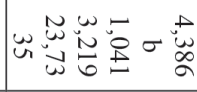 & 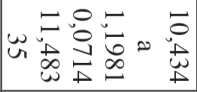 & de & \\
\hline 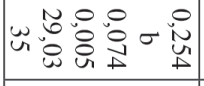 & 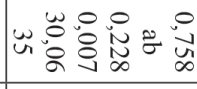 & 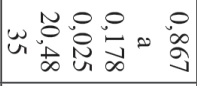 & के & \\
\hline 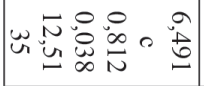 & 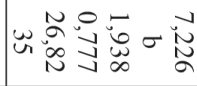 & 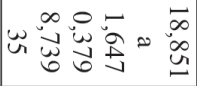 & के & \\
\hline 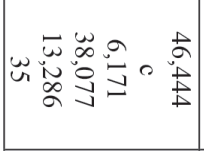 & 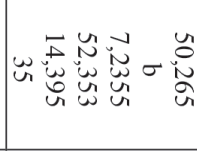 & 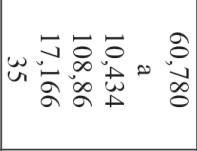 & $\underset{\approx}{3}$ & 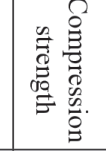 \\
\hline 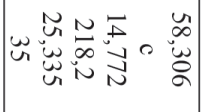 & 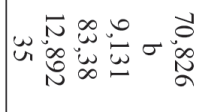 & 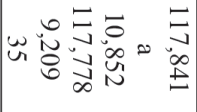 & $3 \stackrel{3}{3}$ & 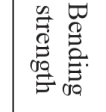 \\
\hline 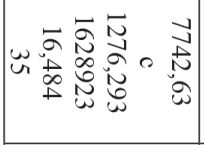 & 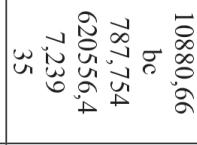 & 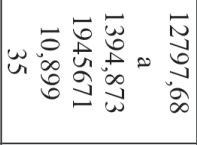 & 3 & 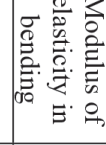 \\
\hline 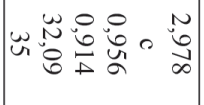 & 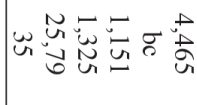 & 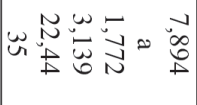 & $\underset{\infty}{3}$. & 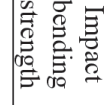 \\
\hline 岕忍 & 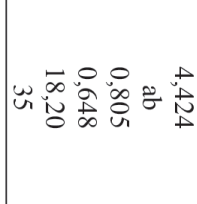 & 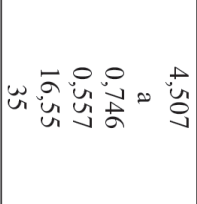 & $\stackrel{a}{r}$ & 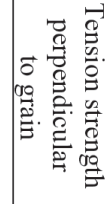 \\
\hline
\end{tabular}

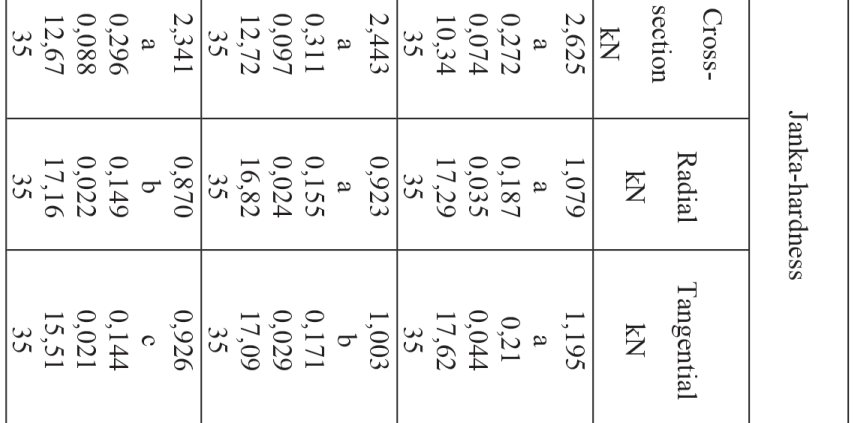


Highest decrease in impact bending strength values were observed when wild cherry samples were treated at $212^{\circ} \mathrm{C}$ for $2,5 \mathrm{~h}$. The decrease was $62,27 \%$ for wild cherry for $2,5 \mathrm{~h}$ of treatment time at $212^{\circ} \mathrm{C}$.

Decrease in tension strength perpendicular to grain was found to be $18.99 \%$ for wild cherry compared to the untreated control samples, when treated at $212^{\circ} \mathrm{C}$ for $2,5 \mathrm{~h}$.

According to these results, the lowest decreases in tangential, radial, and longitudinal janka hardness values $\left(22,53 ; 19,35\right.$; and $10,83 \%$, respectively) were observed in the samples treated at $212^{\circ} \mathrm{C}$ for $2,5 \mathrm{~h}$. Sundqvist et al. (2006) found that treatments for birch at $180^{\circ} \mathrm{C}$ for 1 to 2,5 hours reduced strength and hardness significantly. Losses in mechanical properties can be linked to the mass loss and increase in formic and acetic acid concentrations.

Mechanical properties of heat-treated wood, although not explicitly specified, appear to have been generally tested at constant ambient conditions. The reasons for the change in mechanical properties hasbeen extensively discussed by Korkut and Kocaefe (2009). The degradation of hemicelluloses has been proposed as the major factor for the loss of mechanical strength, affecting especially bending and tensile strength, but also the crystallization of amorphous cellulose might play an important role.

Polycondensation reactions of lignin, resulting in cross-linking, are mentioned as having a positive impact on the mechanical properties of heat-treated wood mainly in the longitudinal direction. The differences between the compressive resistance parallel to the fibre (increase) and compressive strength radial (decrease) are attributed to the anisotropy of crystalline cellulose. The mechanical behaviour of wood is strongly dependent on its moisture content below the FSP The lower equilibrium moisture content might affect positively the strength properties of heat-treated wood under service conditions, but this effect is superseded by the degradation of the chemical compounds (Borrega 2011).

Table 2 shows the level of decrease in various physical and mechanical properties of wild cherry wood with increased thermal treatment duration.

Table 2. Percentage decrease of some properties in wild cherry wood following heat treatment for different durations.

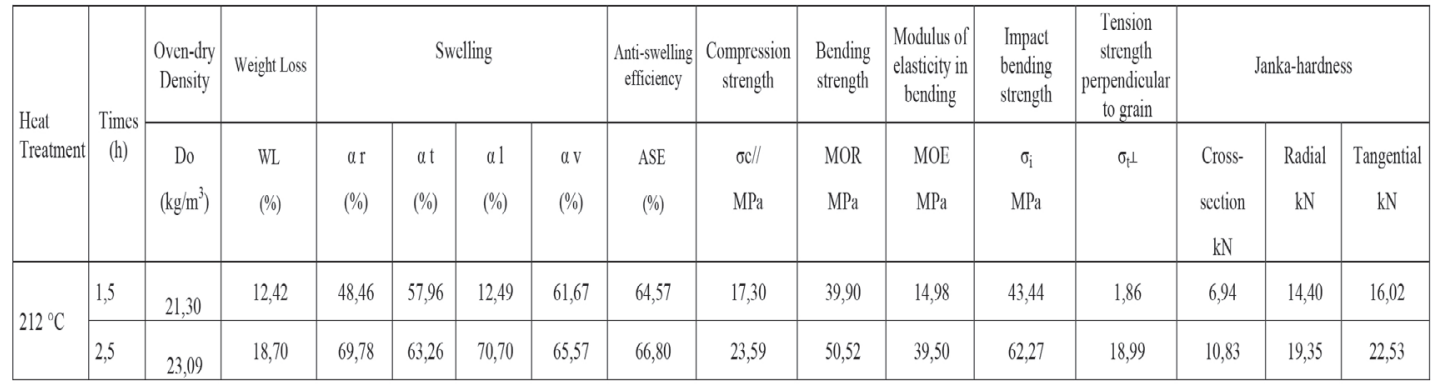

In this study, the physical and mechanical properties of wild cherry wood were determined by heat treatment at different durations. These properties can be compared with the results of other studies (Tjeerdsma et al. 1998, Zaman et al. 2000, Sundqvist et al. 2006, Shi et al. 2007, Gunduz et al. 2009) in literature which are related to the effects of different durations on physical and mechanical properties of different tree species. 


\section{CONCLUSIONS}

In conclusion, it was found that the some physical properties (oven-dry density and swelling) and mechanical properties (compression strength parallel to grain, bending strength, modulus of elasticity in bending, janka-hardness (cross-section, radial, tangential), impact bending strength and tension strength perpendicular to grain) of the wild cherry decreased for the heat treatment times studied compared to the properties of their untreated counterparts.

Due to its more attractive darkened color, decreased moisture performance and improved stability attributes, heat-treated wild cherry can be used in applications where they had no use previously. Further studies are in progress to determine if heat treatment effects on the the microscopic structure, chemical composition and combustion properties of wood.

\section{REFERENCES}

Boonstra M.J. 2008. A two-stage thermal modification of wood. Ph.D. dissertation in cosupervision Ghent University and Université Henry Poincaré - Nancy 1, 297p.

Borrega, M. 2011. Mechanisms affecting the structure and properties of heat-treated and high-temperature dried Norway spruce (Picea abies) wood. University of Eastern Finland Faculty of Science and Forestry School of Forest Sciences, Dissertationes Forestales 134. 52 p.

Brito, J.O.; Garcia, J.N.; Bortoletto, G.Jr.; Pessoa, A.M.C.; Silva, P.H.M. 2006. The density and shrinkage behavior of Eucalyptus grandis wood submitted to different temperatures of thermoretification. Cerne 12(2):182-188.

Esteves, B. M.; Pereira, H. M. 2009. Wood modification by heat treatment: A review. BioResources 4(1): 370-404.

Eşen, D.; Yildiz, O.; Kulaç, S.; Sarginci, M. 2005. Neglected valuable leafy type of Turkey's forests: Wild cherry, (Cerasus avium (L.) Monench) or syn. Prunus avium L.). J Chamber of Forest Engineer (TBMMO) 2: 18-22.

FTWA. 2003. ThermoWood Handbook. Finnish ThermoWood Association. Helsinki-Finland.

Gunduz, G.; Korkut, S.; Aydemir, D.; Bekar, İ. 2009. The Density, Compression Strength and Surface Hardness of Heat Treated Hornbeam (Carpinus betulus L.) Wood. Maderas. Ciencia y tecnología 11(1): 61-70.

International Organization for Standardization. ISO. 1976. Standard atmospheres for conditioning and/or testing - Specifications, ISO 554, Switzerland.

International Organization for Standardization. ISO. 1982. Wood-Sampling sample trees and logs for determination of physical and mechanical properties of wood in homogeneous stands. ISO 4471, Switzerland.

International Organization for Standardization. ISO. 1975. Wood determination of density for physical and mechanical tests, ISO 3131, Switzerland.

International Organization for Standardization. ISO. 1982. Wood-Determination of radial and tangential swelling. ISO 4859, Switzerland. 
International Organization for Standardization. ISO. 1975. Wood sampling methods and general requirements for physical and mechanical tests. ISO 3129, Switzerland.

International Organization for Standardization. ISO. 1976. Wood tests methods-Determination of ultimate stress in compression parallel to grain. ISO 3787, Switzerland.

International Organization for Standardization. ISO. 1975. Wood-Determination of ultimate strength in static bending. ISO 3133, Switzerland.

International Organization for Standardization. ISO. 1975. Wood-Determination of modulus of elasticity in static bending. ISO 3349, Switzerland.

International Organization for Standardization. ISO. 1975. Wood-Determination of static hardness. ISO 3350, Switzerland.

International Organization for Standardization. ISO. 1975. Wood-Determination of impact bending strength. ISO 3348, Switzerland.

International Organization for Standardization. ISO. 1975. Wood-Determination of ultimate tensile stress perpendicular to grain. ISO 3346, Switzerland.

International Organization for Standardization. ISO. 1975. Wood-Determination of moisture content for physical and mechanical tests. ISO 3130, Switzerland.

Korkut, S.; Kocaefe, D. 2009. Effect of heat treatment on wood properties. Duzce University Journal of Forestry 5(2): 11-34.

Li, X.; Cai, Z.; Mou, Q.; Wu, Y.; Liu, Y. 2011. Effects of heat treatment on some physical properties of Douglas-fir (Pseudotsuga menziesii) wood. Advanced Materials Research 197-198:90-95.

Mohareb, A.; Sirmah, P.; Pétrissans, M.; Gérardin, F. 2012. Effect of heat treatment intensity on wood chemical composition and decay durability of Pinus patula. Eur J Wood Prod 70: 519-524.

Shi, J.; Kocaefe, D.; Zhang, J. 2007. Mechanical behaviour of Quebec wood species heat-treated using ThermoWood process. Holz Roh-Werkst 65: 255-259.

Sundqvist, B.; Karlsson, O.; Westermark, U. 2006. Determination of formic acid and acetic acid concentrations formed during hydrothermal treatment of birch wood and its relation to colour strength and hardness. Wood Science and Technology 40(7): 549-556.

Tjeerdsma, B.; Boonstra, M.; Militz, H. 1998. Thermal modification of non-durable wood species. Part 2. Improved wood properties of thermally treated wood. International Research Group on Wood Pre., Document no. IRG/WP 98-40124.

Zaman, A.; Alen, R.; Kotilainen, R. 2000. Heat behavior of Pinus sylvestris and Betula pendula at 200$230^{\circ}$ C. Wood Fiber Sci 32(2): 138-143. 